\title{
Inter-year variation in pup production of Caspian seals Pusa caspica 2005-2012 determined from aerial surveys
}

\author{
Lilia Dmitrievaa ${ }^{1, *}$, Tero Härkönen ${ }^{2}$, Mirgaliy Baimukanov ${ }^{3}$, Anders Bignert ${ }^{2}$, \\ Ivar Jüssii ${ }^{4}$, Mart Jüssii ${ }^{4}$, Yesbol Kasimbekov ${ }^{3}$, Mikhail Verevkin ${ }^{5}$, Vadim Vysotskiy ${ }^{6}$, \\ Susan Wilson ${ }^{7}$, Simon J. Goodman ${ }^{1, *}$ \\ ${ }^{1}$ School of Biology, University of Leeds, Leeds LS2 9JT, UK \\ ${ }^{2}$ Swedish Museum of Natural History, Box 50007, Stockholm 10405, Sweden \\ ${ }^{3}$ Institute of Hydrobiology \& Ecology, Karasaysky Raion, Almaty 040916, Kazakhstan \\ ${ }^{4}$ Estonian Fund for Nature, PO Box 245, Tartu 50002, Estonia \\ ${ }^{5}$ St. Petersburg State University, Universitetskaya nab.7/9, St. Petersburg 199034, Russia \\ ${ }^{6}$ Zoological Institute, RAS, Universitetskaja nab. 1, St. Petersburg 199034, Russia \\ ${ }^{7}$ Tara Seal Research, Killyleagh, Co. Down BT30 9QN, UK
}

\begin{abstract}
Assessing species abundance and reproductive output is crucial for evaluations of population dynamics, conservation status and the development of management objectives. The Caspian seal Pusa caspica is a key predator in the Caspian Sea ecosystem and is listed as Endangered by the IUCN. Here we report on fixed-wing aerial strip transect surveys of the breeding population on the Caspian Sea winter ice field carried out in February, 2005-2012. Potential detection biases were estimated by applying a Petersen mark-recapture estimator to the counts from double photographic observations. We also tested for effects of weather conditions on count results, and for correlations between pup production and ice conditions and net primary productivity (npp). Fluctuations in pup production estimates were observed among years, ranging from 8200 pups (95\% CI: 7130-9342) in 2010 to 34000 (95\% CI: 31 275-36 814) in 2005. Total adults on the ice ranged from 14500 in 2010 to 66300 in 2012. We did not detect significant associations between pup production and either ice summary data (ice season length and ice area) or npp. The observed inter-year variation may be partly due to underlying biological drivers influencing the fecundity of the population, although measurement errors arising from observation bias, plus variation in survey timing and weather conditions may also have contributed. Identifying the potential drivers of Caspian seal population dynamics will require extending both the survey time series and the quality of supporting data. However, inter-year fluctuations should still cause concern that the population may be vulnerable to environmental variability and ecosystem dynamics.
\end{abstract}

KEY WORDS: Caspian Sea $\cdot$ Kazakhstan - Russian Federation - Pinniped - Marine mammals · Abundance $\cdot$ Strip survey $\cdot$ Mark-recapture

\section{INTRODUCTION}

Assessing species abundance is crucial for evaluations of population dynamics, conservation status and the development of management objectives (Skalski et al. 2005). Evaluating the abundance and

*Corresponding authors: sealilia@gmail.com,

s.j.goodman@leeds.ac.uk reproduction of ice-breeding pinnipeds provides challenges for population biologists because they are often patchily distributed over large, remote areas, and may be difficult to observe due to ice features and weather conditions. Developing efficient and reliable aerial survey methodologies for ice-breeding Attribution restricted. Authors and original publication must be credited. 
seals is important, as many species may act sentinels for marine ecosystem responses to climate change (Jüssi et al. 2008, Moore \& Huntington 2008), while others require monitoring because they are of conservation concern (Kokko et al. 1998) or are needed to evaluate the impacts of human activities (Sundqvist et al. 2012).

The Caspian seal (Pusa caspica) population declined during the 20th century by around $90 \%$, from an initial population size of $>1$ million. It is classified as Endangered by the IUCN, and continues to be affected by a number of threats, including humancaused mortality and habitat loss (Härkönen 2008, Härkönen et al. 2012, Dmitrieva et al. 2013). Reliable estimates of abundance and reproduction are crucial for monitoring the status of the species and facilitating discussions with regional stakeholders on mitigation, conservation and management issues.

Caspian seals breed on the winter ice-sheet of the northern Caspian during late February and early March. Aerial surveys counting the number of seal pups born on the ice are the most practical way to obtain accurate estimates of the population's pup production, as pups do not leave the ice to feed until after weaning. Pup production estimates reflect population productivity, which is essential in understanding the dynamics and fecundity of the population (Skalski et al. 2005).

Historically, Caspian seal population estimates were mainly based on hunting records, until the 1970s (Dorofeev \& Freyman 1928, Badamshin 1960, 1961, 1966, 1968, 1969, Rumjancev et al. 1975). The first aerial survey was made in 1973 and then repeated in 1976, 1980, 1986 and 1989 (Krylov 1990). These early surveys suggested population sizes of ca. 300000 to 400000 individuals, although the methodological basis of the estimates is not clear.

The first systematic aerial surveys of Caspian seals were conducted in 2005 and 2006, and revealed a decline in pup production of 21000 and 17000 pups in 2005 and 2006, respectively, compared to the previous estimate of 46800 breeding females made in the late 1980s (Krylov 1990, Härkönen et al. 2008). A recent hind-casting analysis based on hunting records suggested a total population size in 1989 of only 128000 seals with 30000 reproductive females (Härkönen et al. 2012).

Aerial visual and photographic strip transect surveys have been successfully used for a range of ice breeding seal species, e.g. harp seals (Potelov 2003, Stenson et al. 2003, Salberg et al. 2008), hooded seals (Bowen et al. 1987) and ringed seals (Krafft et al. 2006, Härkönen et al. 2008). In the case of
Caspian seals, strip transect aerial survey was applied in favour of distance sampling, because the species often forms large breeding colonies which makes it impractical to both count all the animals visually and make distance measurements at the time of the survey.

In this paper we reassess previous survey results from 2005 to 2006 using more accurate values for survey coverage and new results from the present study for 2007 to 2012, to assess the demographic variation and dynamics of the population. We evaluate potential detection biases by applying a Petersen markrecapture estimator to the counts from the doublephotographic observations used in the aerial survey of 2012. A multiple-observer method based on markrecapture models is often used in aerial surveys with line-transect distance-sampling (Quang \& Becker 1997, Buckland et al. 2010) or strip transect sampling (Marsh \& Sinclair 1989, Pollock et al. 2006,) but the application of this method to ice-breeding seals such as Caspian seals is new. Quantification of the recapture estimator allows a correction factor to be applied to directly observed counts, thereby allowing for 'missed' observations. We also tested for effects of weather conditions on count results, which could also introduce bias to results, and for potential correlations between annual pup production and indexes of winter ice conditions and net primary productivity.

\section{MATERIALS AND METHODS}

\section{Study design and instrumentation}

Survey flights were carried out from 2005 to 2012 over 2 wk periods falling between 4 February and 2 March, when most pups were expected to have been born (Table 1). Surveys covered the winter ice sheet in the northern section of the Caspian Sea from the airports in Atyrau (Kazakhstan) and Astrakhan (Russian Federation) (Fig. 1). A L410 high-wing twin turboprop aircraft was used in all survey years in Kazakhstan, while an An-2 biplane and a Mi-8 helicopter were used in Russia in 2008 and 2010-2012, respectively. Aerial surveys were not conducted in Russia in 2005-2006, as flying permits were not issued, and in 2007 and 2009, due to the absence or lack of ice suitable for seal pupping in Russian waters.

The survey method is described in Härkönen et al. (2008). The aircraft was flown at a speed of $250 \mathrm{~km} \mathrm{~h}^{-1}$ at a constant altitude of $90 \mathrm{~m}$, maintained by a radar altimeter, along north-south transects spaced at intervals of $0.1^{\circ}$ longitude (6 longitudinal minutes [6']), 
Table 1. Minimum estimates of numbers of Caspian seals Pusa caspica and eagles (mostly Haliaeetus albicilla) on ice in 20052012. Ice coverage is a percentage of ice covered by transects from the entire survey area. Coefficient of variation (CV, in parentheses) is given for each estimate; $95 \%$ confidence intervals (CI) are shown for the estimate of all pups

\begin{tabular}{|cccccrr|}
\hline Year & $\begin{array}{c}\text { Survey dates; } \\
\text { ice coverage (\%) }\end{array}$ & $\begin{array}{c}\text { All pups (CV); } \\
95 \% \text { CI }\end{array}$ & $\begin{array}{c}\text { Mother-pup } \\
\text { pairs (CV) }\end{array}$ & $\begin{array}{c}\text { Lone } \\
\text { pups (CV) }\end{array}$ & $\begin{array}{c}\text { Single } \\
\text { adults (CV) }\end{array}$ & $\begin{array}{c}\text { Eagles } \\
\text { (CV) }\end{array}$ \\
\hline 2005 & 23-28 Feb; 10.18 & 25086 (4.15); 23046-27127 & $22750(3.69)$ & $2336(15.83)$ & $23776(3.93)$ & $3144(13.61)$ \\
2006 & 21-25 Feb; 10.03 & $19437(7.04) ; 16755-22119$ & $15037(9.78)$ & $4400(9.22)$ & $12123(8.64)$ & $2073(18.19)$ \\
2007 & 24-27 Feb; 12.14 & $7147(6.27) ; 6269-8026$ & $4298(7.87)$ & $2849(8.79)$ & $27245(5.00)$ & $680(33.56)$ \\
2008 & 13 Feb-2 Mar; 13.88 & $6254(5.14) ; 5624-6884$ & $5115(6.16)$ & $1139(12.83)$ & $17514(4.57)$ & $1268(12.93)$ \\
2009 & 4-20 Feb; 10.36 & $19501(8.16) ; 16382-22619$ & $14874(7.37)$ & $4627(11.23)$ & $33878(4.56)$ & $1120(29.81)$ \\
2010 & 7-19 Feb; 9.87 & $6697(6.85) ; 5798-7596$ & $3465(9.96)$ & $3232(9.19)$ & $5552(6.94)$ & $456(44.73)$ \\
2011 & 8-20 Feb; 12.24 & $21940(5.16) ; 19721-24159$ & $14413(4.96)$ & $7527(5.92)$ & $19514(3.63)$ & $1831(17.06)$ \\
2012 & 11-21 Feb; 9.83 & $22292(6.24) ; 19566-25018$ & $15077(6.31)$ & $7215(8.87)$ & $43980(4.91)$ & $2469(9.83)$ \\
\hline
\end{tabular}

which corresponds to an inter-transect spacing of approximately $8 \mathrm{~km}$ at the study area latitude. The entire range of the potential seal habitat in the ice area was covered, with a target survey fraction of 10 to $11 \%$ of the area. In 2007 and 2011 additional transects were flown bisecting the 6 ' inter-transect interval in the areas where high densities of breeding seals were observed, to improve the accuracy of the estimate. The windows of the aircraft were individually marked for every observer using inclinometers, to limit the sighting angles to $10.2^{\circ}$ (500 m distance) and $42^{\circ}$ (100 $\mathrm{m}$ distance) for each side of the aircraft, which yielded a $400 \mathrm{~m}$ wide strip on each side of the aircraft when viewed at $90 \mathrm{~m}$. The $200 \mathrm{~m}$ wide strip under the aircraft was not surveyed. Only seals within the marked strips were counted, giving a total observed strip width of $800 \mathrm{~m}$.

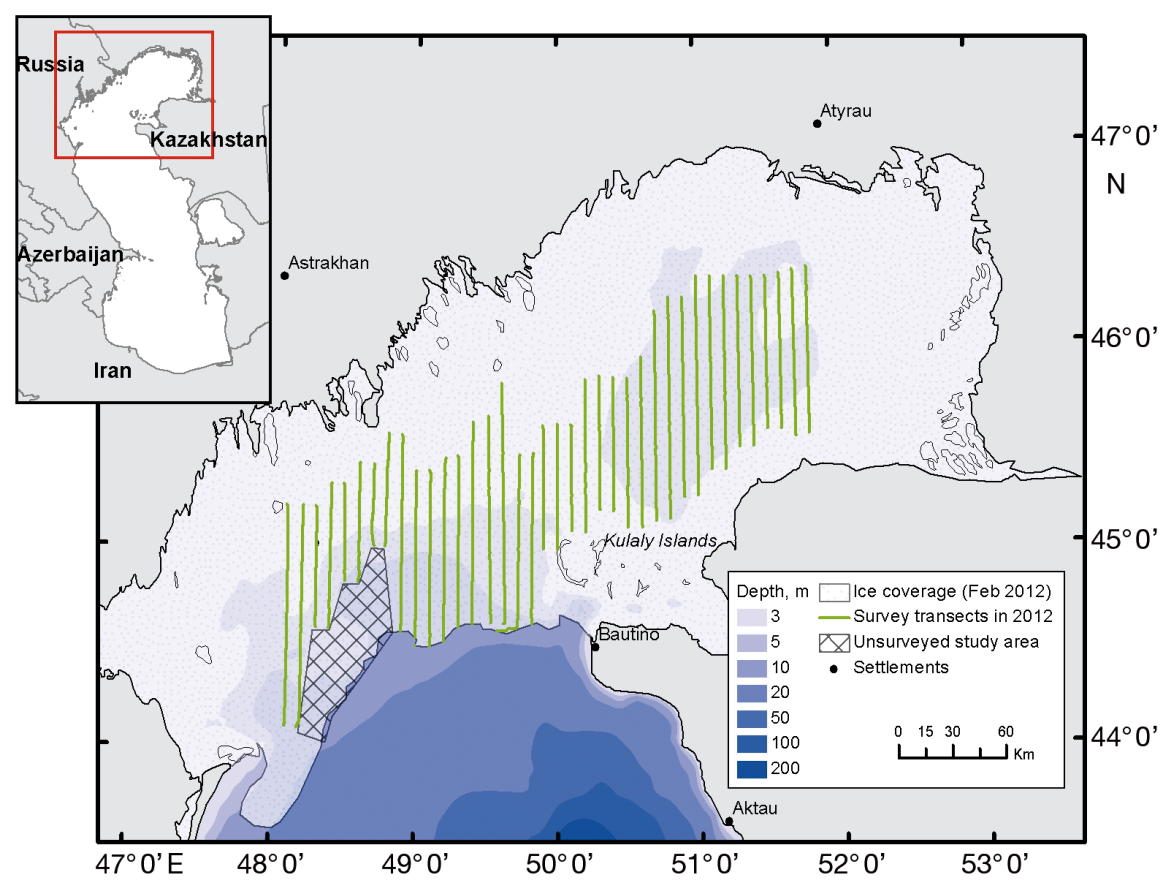

Fig. 1. North Caspian region showing the study area and transects for 2012

\section{Data recording}

Four trained observers, 2 on each side of the aircraft, made observations of pups, mother-pup pairs and adults during the entire survey using dictaphones and marking positions with hand-held GPS units. At least 1 observer on each side took digital, GPS-stamped photographs (serial shooting mode; minimum 8 megapixel sensor resolution, 70 to $200 \mathrm{~mm}$ zoom lens). Pups were defined as whitecoated pups. All animals older than white-coated pups were classed as adults. As far as possible, survey flights were conducted during the peak pupping period, so moulted pups should not be present in large numbers. Visual observation notes to supplement photographs were recorded by all the observers into dictaphones time synchronized with GPS units. Photographs were taken both of visible seal groups/individuals and also potential seal habitats, or indicators of seal presence (e.g. ice ridges, polynias, seal tracks, breathing holes, birthing blood marks, etc.) which were examined later for whitecoated pups.

For 2005 to 2011, the GPS-stamped photographs were taken by one of the observers from each side of the aircraft, while locations of visual observations were registered manually on hand-held GPS units by 
a second observer. In 2012, during 4 survey days in Kazakhstan on 14, 15, 20 and 21 February, both GPSlinked double photographic and visual records were taken by the 2 observers on each side of the aircraft, in order to allow estimation of observation error rates.

\section{Data analysis}

Estimates of seals and eagles on ice in 2005-2011

Each photograph was inspected for the number of mother-pup pairs, lone pups, lone adults (not with a pup) and eagles (natural predators of pups). The total estimates for the numbers of seals were calculated by simple extrapolation of total counts from transects divided by the survey coverage fraction for each area.

Estimates of seals on Russian ice during years where it was not possible to fly in Russian territory (2005, 2006 and 2009) were generated using densities from the Kazakh survey, and the area of ice suitable for breeding seals in the Russian sector. In 2007, there was no ice in Russian territory. In 2006 and 2009, a small, relatively isolated area of breeding ice straddled the border, and estimates for the Russian section were made using the Kazakh density immediately adjacent to the border. For 2005, the breeding ice was more extensive, and so the Russian estimate was based on the average density for Kazakhstan.

Measures of uncertainty for all the counts were based on coefficients of variation (CV) for each category of animals generated using a randomised spatial re-sampling procedure as described by Härkönen et al. (2008), with the computer programme TISS (A. Bignert, Swedish Museum of Natural History, Stockholm, Sweden).

Estimates of seals and eagles on ice and observation errors in 2012

Double-observer photographic data collected during 4 survey days in 2012 provided the opportunity to identify individual animals on multiple GPS-located photographs taken by different observers and thereby estimate possible error in animal detection using mark-recapture analysis (Borchers et al. 2002). In our case this relied on sampling and resampling individual animals from time- and location-referenced photographs taken by different observers.

The photographs were inspected for the number of adults, pups and eagles captured by both observers on each side of the aircraft. Probabilities of detection of adult seals, pups and eagles were calculated separately for each observer by comparing the proportion of seals detected by individual observers to the number of seals recorded by both observers (Borchers et al. 2002); GPS-located photographs from the $1^{\text {st }}$ observer were compared with matched photographs from the $2^{\text {nd }}$ observer, and Petersen's statistics were calculated. Animal positions in relation to different ice features (e.g. ice cracks, ice ridges) were additionally used to identify the same animal groups in the photographs taken by different cameras. The Petersen formula was applied at the transect level (Borchers et al. 2002). Photographic records from single photographic observations in Russia on 11 to 13 February 2012 were corrected using probabilities of detection based on the mark-recapture analysis of double photographic data collected on 14 to 21 February 2012 in Kazakhstan by the same observers.

\section{Correction of 2005-2011 survey estimates}

We compared 3 types of count data collected from the starboard side of the aircraft from 14 to 21 February 2012: data corrected using the Petersen markrecapture estimator, 'uncorrected' data from singlephoto observations only, and 'uncorrected' data compiled on the basis of simple comparisons and extraction of repeated records from the 2 photographic datasets (the method used in 2005-2011). We tested how the estimates from 2007 to 2011 would change if they were based on the counts from photographic records only, corrected with the probabilities of detection calculated for the same observers in 2012. Probability of detection was not known for one of the photoobservers in 2005-2006, so we corrected the estimates of total pups and total adults for these years with the average ratio between original and corrected estimates in 2007-2012.

Effects of weather conditions on seal visibility and counts

The total number of adults and pups recorded per $1 \mathrm{~km}$ of survey track for each transect in 2005-2012 (specified by longitude) and weather parameters (wind speed [knots], air temperature $\left[{ }^{\circ} \mathrm{C}\right]$ and visibility [m]) were used to construct a statistical model. Weather data were derived from 4 stations located in the North Caspian $\left(46^{\circ} 25.71^{\prime} \mathrm{N}, 52^{\circ} 15.73^{\prime} \mathrm{E} ; 44^{\circ}\right.$ $33.40^{\prime} \mathrm{N}, 50^{\circ} 15.00^{\prime} \mathrm{E} ; 46^{\circ} 13.71^{\prime} \mathrm{N}, 52^{\circ} 48.54^{\prime} \mathrm{E}$; and 
$46^{\circ} 26.20^{\prime} \mathrm{N}, 52^{\circ} 53.86^{\prime} \mathrm{E}$ ) for the date and time of each survey transect flown with a $10 \mathrm{~min}$ interval scale. Weather parameters from the station closest to the transect flown were then averaged for each flown transect time. Generalized additive models (GAM) with negative binomial errors were fitted using the 'gam' function in the mgcr Library of $\mathrm{R}$ (Wood 2006); transect and year were set as random effect parameters.

Correlation of annual pup production with ecological and environmental variables

Although no detailed data are available on prey availability for Caspian seals, net primary productivity (npp, the rate of formation of organic biomass from inorganic compounds via photosynthesis accounting for respiration) gives an indication of the amount of organic material available to support marine foodwebs, and could provide an indirect index of food availability in the ecosystem. A time series of monthly npp data $\left(\mathrm{mg} \mathrm{C} \mathrm{m}^{-2} \mathrm{~d}^{-1}\right)$ for the Caspian Sea was extracted from a global $9 \mathrm{~km}^{2}$ grid of monthly npp values from observations by the MODIS satellite system, distributed via NASA's Ocean Color Web (http://oceancolor.gsfc. nasa.gov/). Since the Caspian is a landlocked sea, npp values for the Caspian required reprocessing of the original remote sensing data to remove land filters. Hence, Caspian npp values may potentially be influenced by atmospheric aerosols and other factors, and so may not be directly comparable to standard oceanic npp. However, such potential biases would not affect the correlation analysis in this study. The reprocessed data were provided by Robert O'Malley, Oregon State University, Ocean Color Web administrator. Npp data extraction and analysis were done using the R statistical package (R Core Team 2014).

Correlations were tested with Spearman's rank correlation test using annual pup production and the mean npp for the summer months (May to October) of the year preceding the seal surveys, since a female's nutritional status in the year before pupping is one of the factors which can determine a successful pregnancy.

The effect of ice conditions was tested with Spearman's rank correlation test using annual pup production and the ice season summary variables: freezing degree days (FDD); ice season length (number of days between first and last ice); mean, maximum and standard deviation of the fast ice area and the whole ice area for each period 1 January to 28 February in 20052012. Standard deviations were calculated between means for $10 \mathrm{~d}$ periods. The ice data were derived from an open archive of the North EurAsia Climate Centre (NEACC): http://neacc.meteoinfo.ru/actuals and from Alferov et al. (2010).

\section{RESULTS}

\section{Study area and survey coverage}

Based on the transect length and strip width of $800 \mathrm{~m}$, the total area surveyed along transects from 2005 to 2012 yielded survey fractions ranging from 9.8 to $13.9 \%$ of the study area (Table 1 ). The survey polygon areas depended on ice coverage in a particular year and ranged from a minimum of $16140 \mathrm{~km}^{2}$ in 2007 to a maximum of $33965 \mathrm{~km}^{2}$ in 2008 .

\section{Estimates of minimum seal and eagle numbers on ice from 2005 to 2012}

Minimum estimates of seal pups, mothers (adults beside a pup), lone adults (without pups) and eagles on ice from 2005 to 2012 (extrapolated from the survey area fraction) with confidence intervals are given in Table 1. The minimum number of all pups for the whole study area was estimated to range from 6254 in 2008 to 25086 in 2005; lone pups (without a mother observed in close attendance) represented betwen 9 and $48 \%$ of total pup estimates in different years (Table 2). Estimates of lone adults (putative breeding males and non-breeding seals) ranged from 5552 in 2010 to 43980 in 2012. Observers' probabilities of

Table 2. Comparison of population structure of Caspian seals Pusa caspica on the ice, 2005-2012 and ratio of seal pup to eagle estimates

\begin{tabular}{|ccccc|}
\hline Year & $\begin{array}{c}\text { \% of lone pups } \\
\text { pups from total } \\
\text { pup estimate }\end{array}$ & $\begin{array}{c}\text { Total adult } \\
\text { estimate }\end{array}$ & $\begin{array}{c}\text { \% of total } \\
\text { mothers from total } \\
\text { adult estimate }\end{array}$ & $\begin{array}{c}\text { Ratio of pup: } \\
\text { eagle estimates }\end{array}$ \\
\hline 2005 & 9 & 48863 & 51 & $8: 1$ \\
2006 & 23 & 31560 & 62 & $9: 1$ \\
2007 & 40 & 34393 & 21 & $11: 1$ \\
2008 & 18 & 23768 & 26 & $5: 1$ \\
2009 & 24 & 53378 & 37 & $17: 1$ \\
2010 & 48 & 12249 & 55 & $12: 1$ \\
2011 & 34 & 41454 & 53 & $9: 1$ \\
2012 & 32 & 66272 & 34 & \\
\hline
\end{tabular}


detection used for correction of seal counts in 2012 ranged from 0.4 to 0.9 for adults, 0.6 to 0.9 for pairs, 0.3 to 0.9 for lone pups and 0.2 to 0.8 for eagles (Table 3, Fig. 2). The estimated number of eagles ranged from 456 (2010) to 3144 (2005) (Table 1). The eagles were mostly white-tailed sea eagles Haliaeetus albicilla, but it was not always possible to determine individual species from the air.

\section{Correction of 2005-2011 survey data for observer bias}

The double-observer level of detection was higher compared to the detection from single observations for all groups (Table 4, Fig. 3). Comparison of 'original' estimates with the estimates 'corrected' by detection probability for the same observers in 2012 for both total pups and total adults are presented in Table 5 and Fig. 4 for each survey year. The 'corrected' estimates were higher by approximately 20 to $30 \%$ for pups and 10 to $40 \%$ for adults in different years. The average ratio between original and corrected estimates in 2007-2012, which was used to correct 2005 and 2006 estimates, was 0.74 (standard

Table 3. Probabilities of detection (p) of Caspian seal adults, pairs, lone pups and eagles for each observer in 2012. pL1 and pL2: on the port side; pR1 and pR2: on the starboard side of the aircraft; 1 and 2: the front and rear seat positions in the aircraft, respectively

\begin{tabular}{|lcccc|}
\hline Observer & Adults & Pairs & Lone pups & Eagles \\
\hline pL1 & 0.51 & 0.66 & 0.43 & 0.24 \\
pL2 & 0.85 & 0.86 & 0.87 & 0.71 \\
pR1 & 0.42 & 0.73 & 0.58 & 0.74 \\
pR2 & 0.51 & 0.58 & 0.25 & 0.82 \\
\hline
\end{tabular}

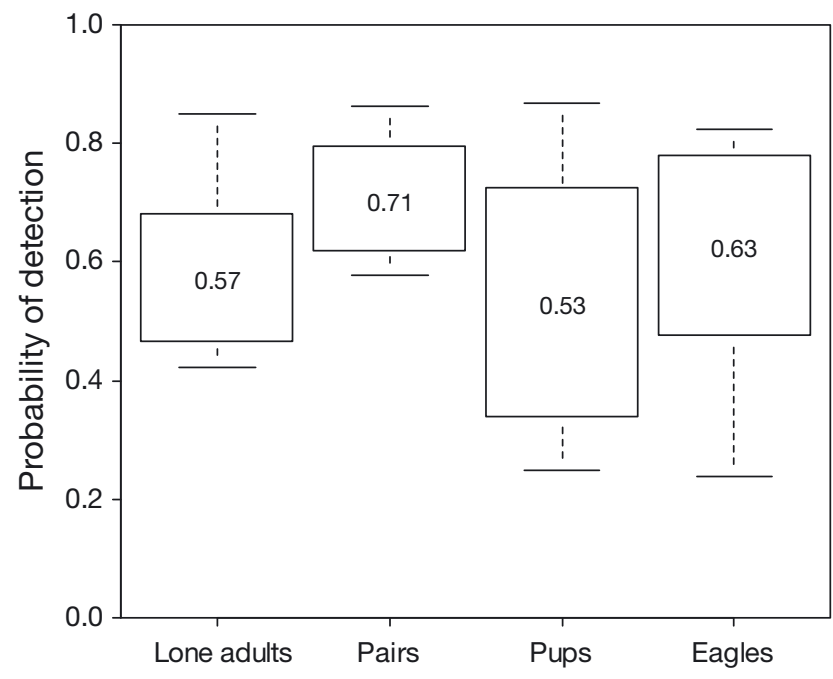

Fig. 2. Probability of detection of eagles and Caspian seals (lone adults, pairs, pubs) for 4 photo-observers. Whiskers indicate minimum and maximum values; mean values are given inside the boxes

deviation $[\mathrm{SD}]=0.05)$ for total pups and $0.78(\mathrm{SD}=$ 0.08 ) for total adults (Table 5). The total estimate of eagles in 2007-2009 and 2011 decreased after correction, which suggests that eagle detection probabilities for photo-observers were lower in these years than in 2012 and visual observers detected more eagles. Therefore we did not apply any correction to eagle counts for 2005-2009 or 2011.

\section{Effects of weather conditions on seal visibility and counts}

We found a significant nonlinear effect of wind and visibility on count results for both adults (wind: $\chi^{2}=$ 34.501, df $=7.52$; visibility: $\chi^{2}=49.292, \mathrm{df}=7.08, \mathrm{p}<$

Table 4. Uncorrected and corrected (by Petersen estimator) 2012 data (counts) from single photographic observations, double photographic observations, and photo- and visual observations for specified dates. Detection was calculated as a ratio of uncorrected data:corrected data by Petersen estimator

\begin{tabular}{|c|c|c|c|c|}
\hline & Lone adults & Pairs & Pups & Eagles \\
\hline $\begin{array}{l}\text { Uncorrected data from single-photo observations (average) from the starboard side } \\
\text { of the aircraft (14-21 Feb) }\end{array}$ & 59 & 58 & 20 & 18 \\
\hline $\begin{array}{l}\text { Uncorrected data from double-photo observations from the starboard side of the } \\
\text { aircraft (14-21 Feb) }\end{array}$ & 90 & 78 & 33 & 22 \\
\hline Petersen estimate for the starboard data (14-21 Feb) & 126 & 88 & 48 & 23 \\
\hline Detection from double-photo observations & 0.72 & 0.88 & 0.69 & 0.95 \\
\hline Detection from single-photo observations & 0.47 & 0.65 & 0.42 & 0.78 \\
\hline Uncorrected data from photo- and visual observations (11-12 Feb) & 1280 & 622 & 341 & 103 \\
\hline Corrected by probability of detection photo-data (11-12 Feb) & 2140 & 777 & 449 & 123 \\
\hline Detection from photo- and visual observations & 0.60 & 0.80 & 0.76 & 0.84 \\
\hline
\end{tabular}




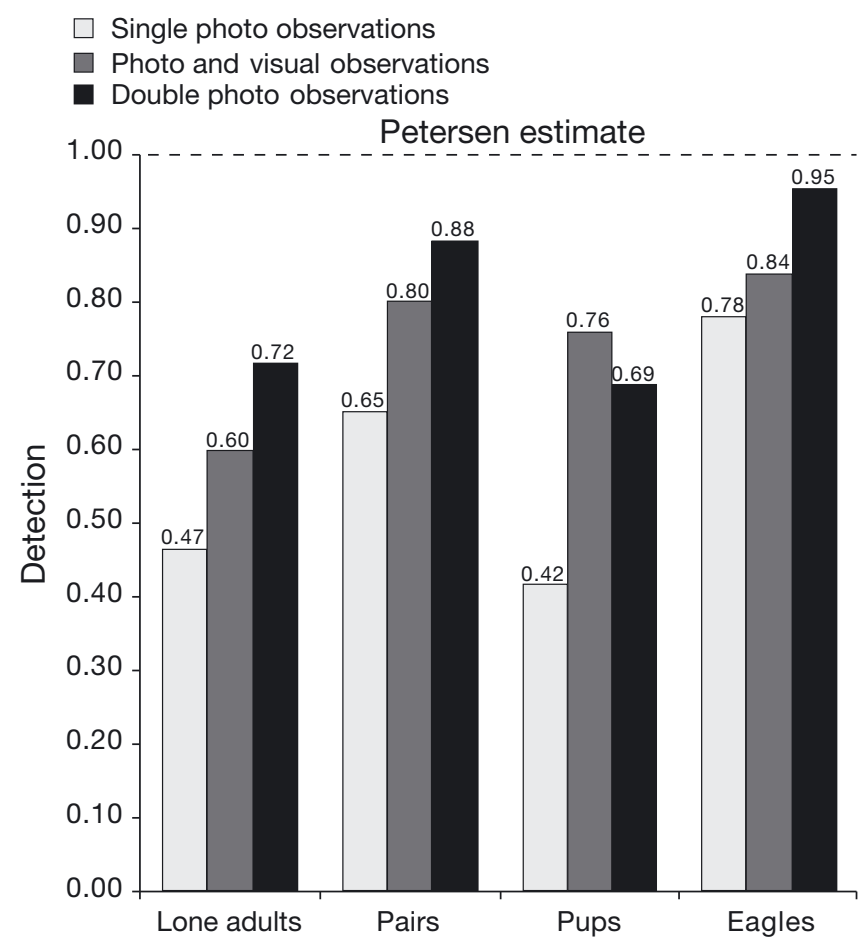

Fig. 3. Comparison of 'uncorrected' 2012 data (counts) compiled from single-photo observations, photo- and visual observations and double-photo observations with the data corrected by the Petersen mark-recapture estimator (shown by a dashed line at the detection rate of 1.0) for Caspian seals (lone adults, pairs, pups) and eagles in 2012. Detection was calculated as a ratio of uncorrected data:corrected data (values at the top of columns)

0.001) and pups (wind: $\chi^{2}=25.967$, df $=6.79$, $\mathrm{p}<$ 0.001 ; visibility: $\chi^{2}=31.262$, df $=6.73, \mathrm{p}<0.001$ ), although these explained a relatively small proportion of the total variation: $\mathrm{r}^{2}=0.19$, with a deviance of 31.1 and $28.3 \%$, for adults and pups, respectively (Fig. 5). The GAM indicates a slight decrease in seals counted

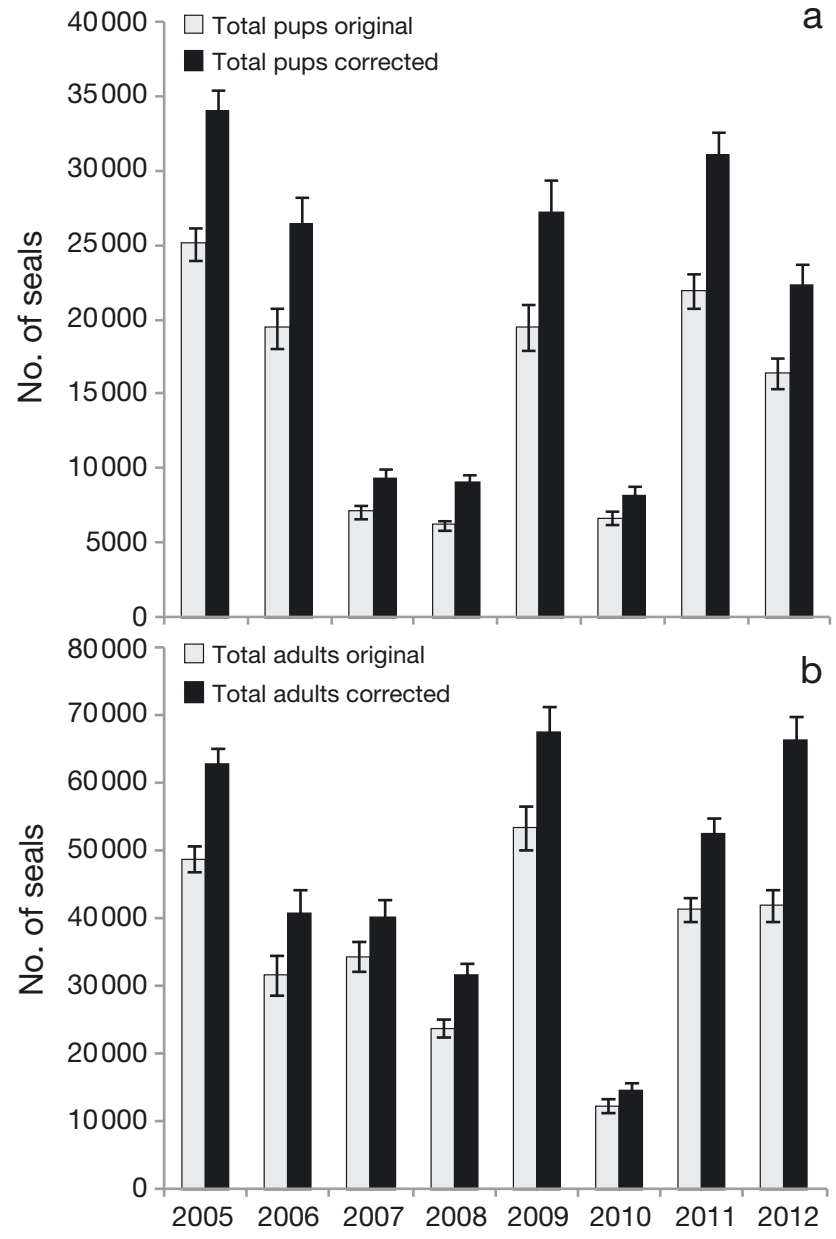

Fig. 4. Comparison of 'uncorrected' (original) estimates of (a) total pups and (b) total adults in 2005 to 2011 and their 'corrected' estimates based on the counts corrected with the probabilities of detection calculated for the same observers in 2012. The difference between 'original' and 'corrected' estimates was calculated as a ratio of uncorrected estimate:corrected estimate. Error bars are 95\% confidence intervals derived from coefficients of variation

Table 5. Pusa caspica. Comparison of uncorrected ('original') estimates of total pups and total adults in 2005-2012 and their 'corrected' estimates. Corrected estimates for 2007-2011 are based on the counts corrected with the probabilities of detection calculated for the same observers in 2012. The difference between 'original' and 'corrected' estimates was calculated as a ratio of uncorrected estimate:corrected estimate. Mean values and their standard deviations (SD) are also shown and were used for correction of the estimates of total pups and total adults for 2005 and 2006

\begin{tabular}{|lcccccc|}
\hline Year & $\begin{array}{c}\text { Total pups } \\
\text { original }\end{array}$ & $\begin{array}{c}\text { Total pups } \\
\text { corrected }\end{array}$ & $\begin{array}{c}\text { Ratio of original: } \\
\text { corrected }\end{array}$ & $\begin{array}{c}\text { Total adults } \\
\text { original }\end{array}$ & $\begin{array}{c}\text { Total adults } \\
\text { corrected }\end{array}$ & $\begin{array}{c}\text { Ratio of original: } \\
\text { corrected }\end{array}$ \\
\hline 2005 & 25086 & 34045 & 0.74 & 48863 & 62924 & 0.78 \\
2006 & 19437 & 26378 & 0.74 & 31560 & 40642 & 0.78 \\
2007 & 7147 & 9371 & 0.76 & 34393 & 40166 & 0.86 \\
2008 & 6254 & 9107 & 0.69 & 23768 & 31764 & 0.75 \\
2009 & 19501 & 27226 & 0.72 & 53378 & 67484 & 0.79 \\
2010 & 6697 & 8236 & 0.81 & 12249 & 14536 & 0.84 \\
2011 & 21940 & 31022 & 0.71 & 41454 & 52688 & 0.79 \\
2012 & 16389 & 22292 & 0.74 & & & 0.63 \\
Mean & & & 0.74 & & & 0.78 \\
SD & & & 0.05 & & & 0.08 \\
\hline
\end{tabular}



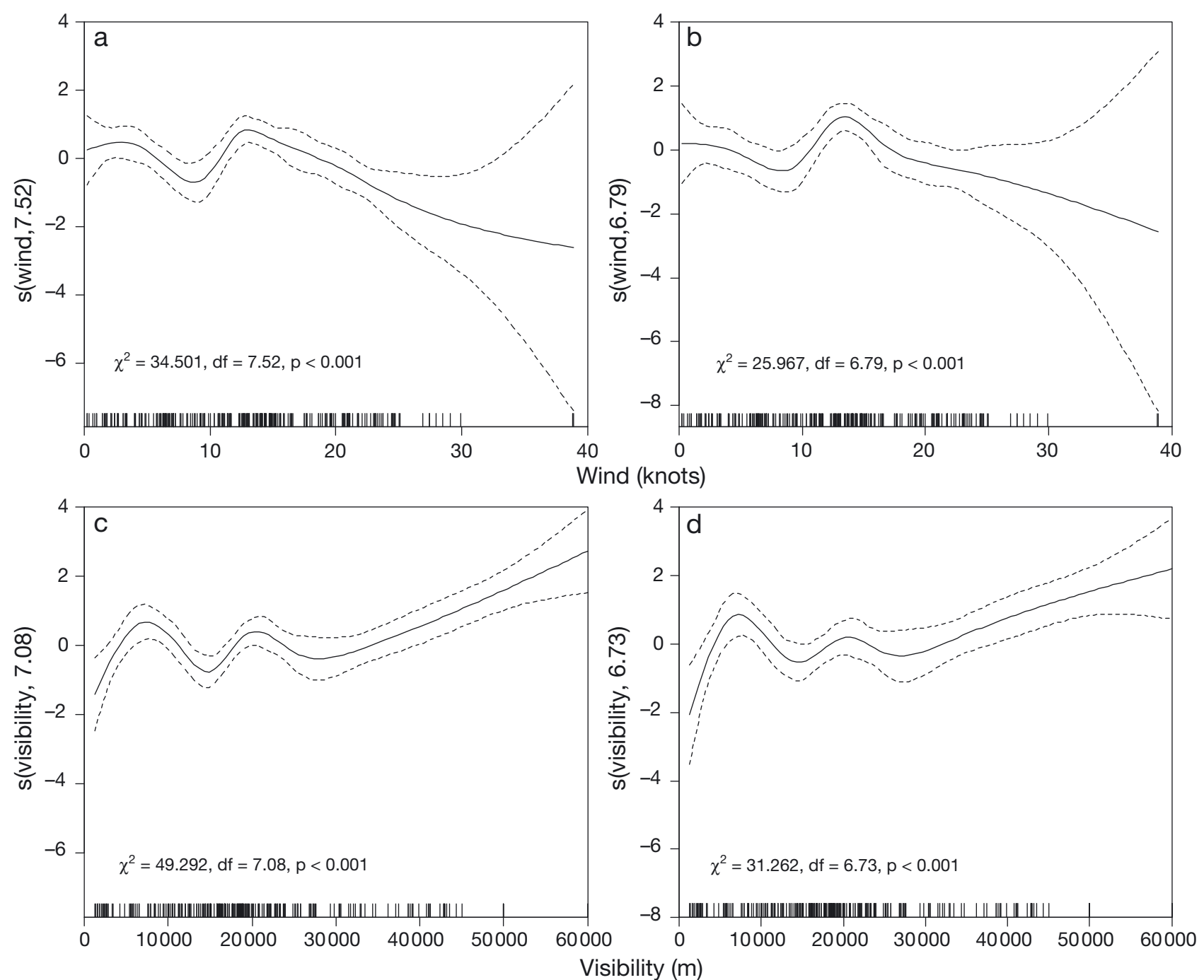

Fig. 5. Smoothing curves and numerical output for wind speed and visibility obtained by additive modelling of Caspian seal adult and pup counts, based on data for all years. The dashed lines are $95 \%$ confidence bands. The vertical axes represent the contribution of wind speed and visibility to the fitted seal counts. $\chi^{2}$ values, degrees of freedom and $p$-values of wind and visibility for adult and pup counts are shown below each graph. (a) Wind speed for adult counts, (b) wind speed for pup counts, (c) visibility for adult counts and (d) visibility for pup counts. The dashes on the $x$-axes represent data values

when wind speed was $>15$ knots and an increase when visibility was $>30000 \mathrm{~m}$ (Fig. 5). Post hoc, pairwise comparison $t$-tests with Bonferroni adjusted pvalues revealed the wind speed in 2010 was higher than that in all other years $(p<0.05)$ except $2006(p=$ $0.2107)$. This suggests that counts in 2010 may have been negatively biased due to higher wind speeds.

\section{Comparison of estimates between 2005 and 2012}

Five fluctuations in pup production of about 65 to $70 \%$ from 2005 to 2006 estimates have been observed since 2005: a decline in 2007, an increase in
2009, a decline in 2010 and an increase in 2011, followed by a decrease in 2012 (Fig. 4). The total pup estimate from the last aerial survey made in 2012, was 22000 pups, which was comparable with 2006 and 2009 estimates (Fig. 4a). The total estimate of adults on the ice in 2012 increased to 66000 , and was not significantly different from the estimates for 2005 and 2009 (Fig. 4b, Tables 6 \& 7). The decreases in 2007, 2008 and 2010 should be treated with caution due to the late completion dates in 2007 and 2008 and high wind speeds in 2010. Results of Spearman's rank correlation test indicate that there was no significant association between annual pup production and summer npp or ice variables $(p>0.05)$ for all 
Table 6. Minimum estimates for the years 2005-2012 corrected by the probability of detection. Ice coverage is a percentage of ice covered by transects from the entire survey area. Coefficient of variation (CV, in parentheses) is given for each estimate; $95 \%$ confidence intervals (CI) are shown for the estimate of all pups

\begin{tabular}{|ccccrrr|}
\hline Year & $\begin{array}{c}\text { Ice coverage } \\
(\%)\end{array}$ & $\begin{array}{c}\text { Total pups (CV); } \\
95 \% \text { CI }\end{array}$ & $\begin{array}{c}\text { Mother-pup } \\
\text { pairs (CV) }\end{array}$ & $\begin{array}{c}\text { Lone pups } \\
(\mathrm{CV})\end{array}$ & $\begin{array}{c}\text { Lone adults } \\
(\mathrm{CV})\end{array}$ & $\begin{array}{c}\text { Eagles } \\
(\mathrm{CV})\end{array}$ \\
\hline 2005 & 10.18 & $34045(4.15) ; 31275-36814$ & $30981(3.69)$ & $3064(15.83)$ & $28879(3.93)$ & $3144(13.61)$ \\
2006 & 10.03 & $26378(7.04) ; 22739-30018$ & $20311(9.78)$ & $6067(9.22)$ & $14263(8.64)$ & $2073(18.19)$ \\
2007 & 12.14 & $9.371(6.27) ; 8219-10523$ & $5102(7.87)$ & $4269(8.79)$ & $30795(5.00)$ & $680(33.56)$ \\
2008 & 13.88 & $9107(5.14) ; 8190-10025$ & $6932(6.16)$ & $2175(12.83)$ & $22656(4.57)$ & $1268(12.93)$ \\
2009 & 10.36 & $27226(8.16) ; 22872-31581$ & $16769(7.37)$ & $10457(11.23)$ & $40258(4.56)$ & $1120(29.81)$ \\
2010 & 9.87 & $8236(6.85) ; 7130-9342$ & $4029(9.96)$ & $4207(9.19)$ & $6300(6.94)$ & $544(44.73)$ \\
2011 & 12.24 & $31022(5.16) ; 27885-34160$ & $17550(4.96)$ & $13472(5.92)$ & $21666(3.63)$ & $1831(17.06)$ \\
2012 & 9.83 & $22292(6.24) ; 19566-25018$ & $15077(6.31)$ & $7215(8.87)$ & $43980(4.91)$ & $2469(9.63)$ \\
\hline
\end{tabular}

Table 7. Population structure of Caspian seals Pusa caspica on the ice, 2005-2012 and ratio of seal pup to eagle estimates. The estimates were corrected by probabilities of detection

\begin{tabular}{|ccccc|}
\hline Year & $\begin{array}{c}\text { Lone pups/ } \\
\text { total pups (\%) }\end{array}$ & $\begin{array}{c}\text { Total adult } \\
\text { estimate }\end{array}$ & $\begin{array}{c}\text { Lone adults/ } \\
\text { total adults (\%) }\end{array}$ & $\begin{array}{c}\text { Pups: } \\
\text { Eagles }\end{array}$ \\
\hline 2005 & 9 & 62924 & 46 & $8: 1$ \\
2006 & 23 & 40642 & 35 & $9: 1$ \\
2007 & 46 & 40166 & 77 & $11: 1$ \\
2008 & 24 & 31764 & 71 & $5: 1$ \\
2009 & 38 & 67484 & 60 & $17: 1$ \\
2010 & 51 & 14536 & 43 & $15: 1$ \\
2011 & 43 & 52688 & 41 & $12: 1$ \\
2012 & 32 & 66272 & 66 & $9: 1$ \\
\hline
\end{tabular}

years (Table 8; Fig. S1 in the Supplement at www.intres.com/articles/suppl/n028p209_supp.pdf). Excluding 2007-2008 and 2010 increased the apparent strength of correlations (with rho values of up to 0.9) for most parameters, indicating potential negative correlations between pup production and ice parameters, and a positive association with npp, but none of these trends were significant. A multiple regression including mean ice area and npp (excluding 20072008 and 2010) also indicated negative correlations between pup production and ice area, and a positive association with npp, with an adjusted $\mathrm{R}^{2}$ of 0.94 (Table S1 in the Supplement at www.int-res.com/

Table 8. Results of Spearman's correlation rank test between annual pup production and ice parameters (2005-2012) and summer net primary productivity (npp). FDD: freezing degree days; no. of ice days: number of days with ice; all ice cover: mean/maximum/standard deviation of whole ice coverage area for the period 1 January to 28 Feburary; fast ice cover: mean/maximum/standard deviation of fast ice area for the period 1 January to 28 February. SD was calculated from means of $10 \mathrm{~d}$ periods (1 January to 28 February); npp values $\left(\mathrm{mg} \mathrm{C} \mathrm{m}^{-2} \mathrm{~d}^{-1}\right.$ ) are for summer months (May to October) in the year preceding the survey. The significance threshold was set at 0.05

\begin{tabular}{|c|c|c|c|c|c|c|c|c|c|}
\hline \multirow{2}{*}{$\begin{array}{l}\text { No. of ind. } \\
(2005-2012)\end{array}$} & \multirow[t]{2}{*}{ FDD } & \multirow{2}{*}{$\begin{array}{c}\text { No. of } \\
\text { ice days }\end{array}$} & \multicolumn{3}{|c|}{ Total ice cover $\left(\times 1000 \mathrm{~km}^{2}\right)$} & \multicolumn{3}{|c|}{ Fast ice cover $\left(\times 1000 \mathrm{~km}^{2}\right)$} & \multirow{2}{*}{$\begin{array}{l}\text { npp summer } \\
(2004-2011)\end{array}$} \\
\hline & & & Mean & Max. & $\mathrm{SD}$ & Mean & Max. & $\mathrm{SD}$ & \\
\hline 34045 & 419 & 120 & 52 & 75 & 18.55 & 14.17 & 25 & 8.61 & 3424.2 \\
\hline 26378 & 635 & 116 & 78.83 & 95 & 11.39 & 42.17 & 60 & 14.22 & 3609.0 \\
\hline 9371 & 199 & 121 & 31 & 77 & 24.48 & 6.33 & 35 & 14.09 & 3611.4 \\
\hline 9107 & 806 & 125 & 79.67 & 87 & 6.89 & 29.83 & 63 & 16.55 & 3512.3 \\
\hline 27226 & 537 & 109 & 67.17 & 77 & 10.26 & 22.17 & 35 & 11.48 & 3450.7 \\
\hline 8236 & 660 & 114 & 70.33 & 83 & 12.14 & 22 & 40 & 13.56 & 4200.9 \\
\hline 31022 & 639 & 121 & 56.83 & 73 & 18.95 & 15.83 & 35 & 13.2 & 3357.8 \\
\hline 22292 & 941 & 171 & 73 & 92 & 20.73 & 23.67 & 45 & 15.06 & 2960.9 \\
\hline \multicolumn{10}{|l|}{ All years } \\
\hline Spearman's rho & -0.428 & -0.144 & -0.428 & -0.539 & 0.119 & -0.238 & -0.634 & -0.666 & -0.642 \\
\hline $\mathrm{p}$-value & 0.299 & 0.734 & 0.299 & 0.168 & 0.793 & 0.582 & 0.091 & 0.083 & 0.096 \\
\hline \multicolumn{10}{|c|}{ Excluding 2007-2008, 2010} \\
\hline Spearman's rho & -0.7 & -0.2 & -0.9 & -0.8 & -0.2 & -0.9 & -0.872 & -0.9 & 0.1 \\
\hline p-value & 0.233 & 0.783 & 0.0833 & 0.1333 & 0.783 & 0.0833 & 0.053 & 0.083 & 0.95 \\
\hline
\end{tabular}


articles/suppl/n028p209_supp.pdf). The overall model was indicated as significant at the 0.05 level, though with the current sample size p-values cannot be estimated reliably.

\section{DISCUSSION}

\section{Data accuracy and observation error}

Visibility bias can cause underestimation of population density for any survey methodology or technology, and it is important to calculate it and adjust estimates accordingly (Pollock \& Kendall 1987, Marsh \& Sinclair 1989). The main assumption of strip-transect analysis that all animals within a transect are detected was not met in our study. Although a survey altitude of $90 \mathrm{~m}$ was expected to give adequate resolution of seals on the ice for both visual observation and photography (Härkönen et al. 2008), there was still bias in detection of all classes of individuals revealed using the mark-recapture analysis from double-observer photographic data collected in 2012.

When using mark-recapture estimators it is important to address observation heterogeneity in the surveyed population, and a large number of modelling approaches exist to account for sources of bias and error (Borchers et al. 2002). This may involve fitting a detection function with survey parameters (e.g. speed, altitude, observer identity, distance from observer) and meteorological conditions at the point of observation as covariates. In our case, survey parameters (aircraft speed and altitude) were fixed, the observers did not change, distances within the surveyed strip were not stratified, and the weather parameters were only available for the nearest weather station to a transect, rather than the point of observation. The age class of animals (pups or adults) and the pup category (lone pups or pups with mothers) were the variables causing heterogeneity in our population, which we have addressed by animallevel stratification, with capture functions estimating abundance of seals of each class separately. With this scenario no model application was necessary (Borchers et al. 2002), and we opted to use the Petersen approach, since other potential sources of variation were either fixed (survey parameters) or data were not available (weather at point of observation). Disturbance from the survey aircraft could have been another source of error by potentially causing some animals to move into the water before being observed. However, the speed and altitude of the sur- vey meant that by the time any animal did react the aircraft was passing overhead, and the animals on neighbouring transect lines would not be affected. Therefore, 'unobservable' animals caused by disturbance were likely to be minimal.

Uncorrected count results were closer to their corrected estimates for eagles and mother-pup pairs than for lone adults and lone pups due to a higher probability of detection for the former categories (see Table 4, Fig. 3). Eagles are likely to be easier to detect because of their conspicuous shape and because they often launch into the air as the aircraft passes. High density aggregations of mother-pup pairs and the presence of blood in the pupping areas can also facilitate their detection on ice. Doubleobserver photographic data collection increased the level of detection compared to single observations for all groups. Usage of 'double-photo' collection instead of 'single-photo plus visual observations' not only improved detection but also made it possible to correct data by the Petersen mark-recapture estimator. However, some animals close to the track line or at the edge of the survey strip, lone pups and seals distantly separated from the breeding colonies might not have been detected by both observers.

Fixed strip-transect sampling is still considered to be a practical approach when animals occur at high densities (e.g. ice-breeding seal colonies) due to the difficulty of using distance sampling, i.e. accurately measuring distances or assigning animals to distance classes at speeds travelled by survey aircraft (Buckland et al. 2001). In this case, the number of animals is recorded from visual or instrumental observations, e.g. photography and infrared imagery in walruses (Burn et al. 2006, Speckman et al. 2011) and harp seals (Chernook \& Boltnev 2008, Oigard et al. 2014). Using infrared imaging in combination with photography (e.g. Burn et al. 2006, Chernook \& Boltnev 2008) may avoid some aspects of detection bias associated with the visibility of seals on ice and, therefore, may improve precision, but cannot eliminate observation error completely. However, the logistical and financial constraints of getting a suitably equipped aircraft into Kazakhstan have, to date, made the use of infrared imaging instrumental surveys impossible. Therefore, we consider double-observer photographic data collection the best option available at this time and recommend its use for future Caspian seal population surveys until appropriately equipped aircraft are available for instrumental recording surveys. Double-observer photographic surveys may also be most appropriate for surveys of 
other ice-breeding seal species, such as Ladoga ringed seals and possibly Baikal seals.

The probabilities of detection we determined were within the range of those estimated from similar population studies of other species (e.g. Buckland et al. 2001). Detection probability estimates varied from 0.2 to 0.9 , and can be affected by many factors including distance from the observation platform, observers' experience, tiredness, weather conditions, etc. (Pollock et al. 2006, Southwell et al. 2008). In animal surveys the detectability decreases with increasing distance (Burnham et al. 1985, Buckland et al. 2001). Therefore, modelling a detection function in relation to the distance from the aircraft based on image analysis would improve our estimates. However, animals which are hard for one observer to see are also likely hard for another to see (e.g. pups behind and under ice ridges) and can result in negative biases for estimates. Such problems will apply to all survey methodologies, including infra-red/ thermal instrumentation. However, they can be minimised by choosing favourable weather conditions for aerial surveys (i.e. with good visibility) and avoiding days with strong winds that may cause pups to shelter behind ice ridges and adults to enter the water.

\section{Potential effect of weather conditions on count results}

We found significant nonlinear effects of wind and visibility on count results for both adults and pups. Although the model cannot be used for prediction/ data correction because it does not take into account other environmental factors that may affect recorded seal numbers (e.g. ice parameters, depth, distance from shore), it suggests that very high visibility increases the probability of detection. Strong winds may affect both the presence of adult seals on ice and the probability of detection of pups, since adults, which may act as markers for the presence of pups, take refuge in the water under such conditions. Moreover, pups may not only be harder to detect without adults present (minimum probability of detection for lone pups in 2012 was as low as 0.3), but they may also shelter from wind under overhanging ice ridges and, therefore, be hidden from the observer. This behaviour presents problems for all survey technologies. Wind speed during the 2010 aerial survey was significantly higher than it was in at least 6 other survey years. This may account for the highest recorded proportion of lone pups (48\%) and the low estimates of pups and adults on the ice in 2010. Although high visibility demonstrated a certain positive effect on count results, no negative effect of low visibility was observed. This may be related to the fact that survey flights were not carried out in low-visibility conditions. Visibility levels can also be very patchy in the Caspian (e.g. local fog), and the stations where measurements were made were not necessarily close to the transects.

Behavioural data from satellite-tagged seals during the pupping period could be used in the future to create a model that can predict the proportion of adult seals hauled out under various meteorological conditions. Applying this model to the count data could further refine population estimates by accounting for the influence of meteorological conditions for each survey flight. All surveys of ice-breeding seals, regardless of technology, should account for potential biases arising from weather and ice conditions.

\section{Variation among the years 2005 to 2012}

After bias correction, minimum pup production estimates from 2005 to 2012 increased by 20 to $30 \%$ as compared with the 'original' estimates (Table 5, Fig. 4a). However, correcting estimates did not affect the pattern of annual variation in pup production observed during 2005-2012, revealing 5 inter-year fluctuations between consecutive years. This variation is likely to arise through a combination of biological factors and measurement errors stemming from observer bias, variation in survey timing, weather and other environmental factors among years.

Such inter-year fluctuations are unlikely to be related to mortality in breeding age classes, since the significant increases observed in 2009 and 2011 were not caused by recruitment in the population. It is more likely that a proportion of females did not participate in breeding in some years with low pup production. There are no recent data on fertility rates of Caspian seals, although early Soviet publications reported that 30 to $60 \%$ of adult females did not participate in breeding in various years (Badamshin 1966, Vorozhcov et al. 1972). Fertility can be reduced by organochlorine pollutants, which accumulate in a seal's body with age and, therefore, can lead to lower recruitment and an ageing population (Hall et al. 1999, Kajiwara et al. 2008). However, any change in the contaminant level in the population of adult females would be gradual and not cause extreme variation among years. Moreover, the most recent contaminant data available collected during the 
2000-2001 canine distemper virus (CDV) outbreak suggest contaminant concentrations are below the threshold for large impacts on fertility (Helle et al. 1976, Wilson et al. 2014).

The potential changes in reproductive rate could reflect local environmental factors such as availability/quality of food. Boyd $(1991,2000)$ suggested that completion of pregnancy in pinnipeds is sensitive to female body reserves which are accumulated continuously during the pregnancy. Females may make a 'decision' to proceed with the pregnancy at implantation, which follows 3 months after mating, and this period might be the time when environmental factors such as food resources and weather conditions are the most important. Similar annual pup production fluctuations have been registered in the Barents Sea harp seal population, where sudden declines have been observed following collapses in Barents Sea capelin stocks (Haug \& Nilssen 1995, Chernook \& Boltnev 2008). Invasive species (such as Mnemiopsis leidyi) have had a serious impact on the Caspian ecosystem (Schaber et al. 2011). Sprat ('kilka') - one of the most important species in Caspian seal diet-is thought to have declined due to the impact of Mnemiopsis on zooplankton (Huraskin \& Zakharova 2001) and kilka overharvesting in 2001-2004 (Daskalov \& Mamedov 2007). Here we used npp as a potential proxy for food availability. Although no significant association between annual pup production and summer npp was detected, the pattern observed for the 5 years without potentially confounding weather effects during surveys is consistent with such predictions. Exploring such associations further would be warranted if the time series is extended. Therefore, at this time, we cannot discount an influence of food availability on pup production.

No significant correlation was found between annual pup production and any ice parameter, but there were negative associations between pup estimates and most ice parameters. Although 2007 (when a significant drop in pup estimate was observed) had poor ice coverage and duration, 2008 and 2010, also with low pup numbers, had normal ice conditions. Mild winters could increase pup mortality, since early loss of the ice breeding platform before weaning would be fatal for Caspian seal pups. Pups avoid going to the water until they moult, and nursing pups forced into the water before the end of lactation are unlikely to survive. A large proportion of pups in 2007 may have died due to unstable ice floes being swept out to sea in storms prior to the relatively late start of the survey on 24 February, and because of easy access for predators to the pupping ice, which was limited to a strip along the north-eastern Caspian coastline that year. The observed increase in adults on the ice in 2012 could be a result of extensive ice coverage in 2012, which may have provided more haul-out habitats for seals in their feeding areas, reducing foraging trip duration and therefore time spent in the water.

Due to the extended pupping period of Caspian seals, some unknown portion of pup production may be missed during surveys, e.g. pups which are born and moulted before the survey or pups that are born after the survey. Thus, in the 2007 survey (24 to 27 February), $57 \%$ of all pups and $81 \%$ of lone pups recorded on the photographs had started to moult or had fully moulted. Although surveys were planned to be conducted in the peak period of pupping, it was not always possible to carry them out simultaneously, due to logistical or weather constraints; this may have affected the compatibility of results between years. In 2005 to 2007 survey flights did not start before the third week of February, while in 2009 to 2012 the surveys had already been completed by that time. In 2008, due to foggy conditions, the survey could not be completed until the beginning of March, when most pups may have already moulted. Some ice movements may have also occurred during that prolonged period of survey, which could have affected the results by moving seals in or out of areas still to be surveyed.

Ideally, the temporal distribution of births should also be estimated in the future to control for the variability in timing and the length of the pupping period (Stenson et al. 2003). The required data on the number and age of pups could be collected from additional reconnaissance flights carried out from the beginning of January, when the first pups are born, and throughout the pupping period until early March (Badamshin 1961). Data collected during annual icebreaker surveys could also contribute to this analysis (Wilson et al. 2008). The method of extrapolating seal numbers to uncovered areas might also affect total estimates. For example in 2012 we applied high densities of adult seals from adjacent transects in the west to the uncovered area of the Russian border. Although these areas form a minor portion of the total breeding surface, they could still cause bias if the density of seals were not the same in the unsurveyed area. Density surface modelling could be applied to uncovered areas, as it does not require equal coverage probability and can be used as a good alternative to design-based extrapolation approaches (e.g. Cañadas \& Hammond 2006, Herr et al. 2009). 


\section{CONCLUSIONS}

The presently available estimates of pup production are likely to be below the true level, due to the extended pupping period of Caspian seals and detection biases. The temporal distribution of births should be measured in the future in order to contribute to pup production estimates. Counts from survey periods with extreme weather conditions, such as those in 2010, should also be treated with caution. Despite the limitations discussed here, photography-supported observations present benefits in terms of cost and ease of application, and, providing limitations are accounted for, can be used for measurement of relative abundance and trends in Caspian and other ice breeding seal populations. Nevertheless, at least 1 instrumental aerial survey using thermal imaging equipment should be conducted for the whole population in both Russia and Kazakhstan. This would enable a comparison of the double-observer photographic method with the instrumental data, in order to calibrate the results from the former method, which may be more practical for regular surveying in the Caspian and, potentially, elsewhere.

The differences in pup production among years are a cause for concern that underlying biological drivers may influence the fecundity of the population and that the population may be sensitive to future climate and environmental change. Such biological drivers could be related to food availability, invasive species, or other broad changes to the Caspian ecosystem. However, identification of the causes remains largely intractable at this time, due to the absence of supporting ecological and environmental data of sufficient resolution (e.g. data on seal diet and food availability), and the still relatively short time series of surveys. It is important to differentiate between local, short-term factors (e.g. ice coverage, weather, food accessibility) and large-scale, long-term parameters (e.g. mortality, changes in the food-web trophic structure, pollution, climate change) affecting annual pup production. Caspian seal aerial surveys should be continued in future years in order to capture longterm trends in the population and factors that may affect pup production, and to guide conservation management decisions.

Acknowledgements. We thank Prof. Viacheslav Zaitsev and Andre-Serge Mikouiza of the International Oceanographic Institute, State Technical University, Astrakhan, for their logistical support in Russia, and Hamid Ghaffarzadeh and Igor Mitrofarnov of the Caspian Environment Programme (CEP) for facilitating the early stages of the study in Kazakhstan. We are also grateful to Parvin Farshchi and Elchin Mamedov of the CEP for their kind help with Caspian fisheries data. Financial support for the 2005 survey was provided by a grant to S.J.G. by the CEP, and in 2007 by Darwin Initiative Grant 162-15-24. This project was tied to industrial contracts 2007-360 and 2008-0397 (Quantitative Assessment \& Impacts on Seal Populations) sponsored by the Agip KCO and to the North Caspian Production Operations Company B.V. (NCPOC), which provided financial support in other years under the auspices of the North Caspian Sea Production Sharing Agreement (NCSPSA) Venture. We thank past and current colleagues at Agip and NCPOC in Atyrau, particularly Gulsim Mutysheva, Olivier Pauwels, Nick Tangney, Igor Lukashov, Sagiden Yerbulekov, Vladimir Terentiev, Davide Speranza, Aidyn Sakharbayev, Samat Sarsengaliyev, Dilyara Tuleuova, Sergey Vernyayev, Makhsuda Sattiyeva, Giovanni Rivas, Paul Bartlett, Walter Rizzi, Nick Philip and Stephen Redford, for support in logistics and the provision of meteorological data.

\section{LITERATURE CITED}

Alferov A, Andreeva Z, Bukharov M, Grigorieva O and others (2010) Long-term climatic significant data set creation and analysis system based on satellite data. Sovrem probl dist zondirovaniya Zemli iz kosmosa 7:51-60

Badamshin B (1960) The state of Caspian seal stock. Zool Zh 39:898-905

Badamshin B (1961) Zapasy kaspijskogo tjulenja i puti ih racional'nogo ispol'zovanija. Biol osnovy rybnogo hozjajstva na vodoemah Srednej Azii i Kazahstana 12:59-62

Badamshin B (1966) Kaspijskij tjulen' i ego promyslovoe ispol'zovanie. In: Materialy konferencii 'Biologicheskie osnovy rybnogo hozjajstva na vodoemah Srednej Azii i Kazahstana'. Nauka, Alma-Ata, p 59-62

Badamshin B (1968) Kaspijskij tjulen' i perspektivy ego hozjajstvennogo ispol'zovanija. Tr Kaspijskogo nauchnoissledovatel'skogo instituta rybnogo hozjajstva 24:65-70

Badamshin B (1969) Godovoj cikl zhizni kaspijskogo tjulenja. In: Chetvertoe vsesojuznoe soveshhanie po izucheniju morskih mlekopitajushhih. Academy of Science, Moscow, p 218-222

Borchers D, Zucchini W, Buckland S (2002) Estimating animal abundance: closed populations. In: Dietz K, Gail M, Krickeberg K, Tsiatis A, Same J (eds) Statistics for biology and health. Springer-Verlag, London

Bowen WD, Myers RA, Hay K (1987) Abundance estimation of a dispersed, dynamic population-hooded seals (Cystophora cristata) in the Northwest Atlantic. Can J Fish Aquat Sci 44:282-295

> Boyd IL (1991) Environmental and physiological factors controlling the reproductive cycles of pinnipeds. Can J Zool 69:1135-1148

Boyd IL (2000) State-dependent fertility in pinnipeds: contrasting capital and income breeders. Funct Ecol 14: 623-630

Buckland ST, Anderson DR, Burnham KP, Laake JL, Borchers DL, Thomas L (2001) Introduction to distance sampling. Estimating abundance of biological populations. Oxford University Press, Oxford

Buckland ST, Laake JL, Borchers DL (2010) Doubleobserver line transect methods: levels of independence. Biometrics 66:169-177 
Burn DM, Webber MA, Udevitz MS (2006) Application of airborne thermal imagery to surveys of Pacific walrus. Wildl Soc Bull 34:51-58

Burnham KP, Anderson DR, Laake JL (1985) Efficiency and bias in strip and line transect sampling. J Wildl Manag 49:1012-1018

Cañadas A, Hammond PS (2006) Model-based abundance estimates for bottlenose dolphins off southern Spain: implications for conservation and management. J Cetacean Res Manag 8:13-27

Chernook VI, Boltnev A (2008) Regular instrumental aerial surveys detect a sharp drop in the birthrates of the harp seal in the White Sea. In: Boltunov A (ed) Marine mammals of the Holarctic. Collection of Scientific Papers. Marine Mammals Council, Odessa, p 100-104

- Daskalov GM, Mamedov EV (2007) Integrated fisheries assessment and possible causes for the collapse of anchovy kilka in the Caspian Sea. ICES J Mar Sci 64: 503-511

> Dmitrieva L, Kondakov AA, Oleynikov E, Kydyrmanov A and others (2013) Assessment of Caspian seal by-catch in an illegal fishery using an interview-based approach. PLoS ONE 8:e67074

Dorofeev SV, Freyman SY (1928) Kaspijskij tjulen' i ego promysel vo l'dah. Tr nauchnogo instituta rybnogo hozjaystva 4:3-30

Hall AJ, Duck CD, Law RJ, Allchin CR, Wilson S, Eybator T (1999) Organochlorine contaminants in Caspian and harbour seal blubber. Environ Pollut 106:203-212

Härkönen T (2008) Pusa caspica. In: The IUCN Red List of Threatened Species, Version 20141. IUCN SSC Pinniped Specialist Group, Gland, www.iucnredlist.org/ details/41669/0

Härkönen T, Jüssi M, Baimukanov M, Bignert A and others (2008) Pup production and breeding distribution of the Caspian seal (Phoca caspica) in relation to human impacts. Ambio 37:356-361

Härkönen $\mathrm{T}$, Harding $\mathrm{KC}$, Wilson S, Baimukanov $M$, Dmitrieva L, Svensson CJ, Goodman SJ (2012) Collapse of a marine mammal species driven by human impacts. PLoS ONE 7:e43130

Haug T, Nilssen KT (1995) Ecological implications of harp seal Phoca groenlandica invasions in northern Norway. In: Blix AS, Walloe L, Ultang O (eds) Developments in marine biology; whales, seals, fish and man, Book 4. Norwegian Institute of Fisheries and Aquaculture, Tromsø, p 545-556

Helle E, Olsson M, Jensen S (1976) Polychlorinated biphenil levels correlated with pathological changes in seal uteri. Ambio 5:261-263

> Herr H, Scheidat M, Lehnert K, Siebert U (2009) Seals at sea: modelling seal distribution in the German Bight based on aerial survey data. Mar Biol 156:811-820

Huraskin L, Zakharova N (2001) Monitoring populjacii kaspijskogo tjulenja. Rybn hozjajstvo 4:30-31

> Jüssi M, Härkönen T, Helle E, Jüssi I (2008) Decreasing ice coverage will reduce the breeding success of Baltic grey seal (Halichoerus grypus) females. Ambio 37: 80-85

Kajiwara N, Watanabe M, Wilson S, Eybatov T and others (2008) Persistent organic pollutants (POPS) in Caspian seals of unusual mortality event during 2000 and 2001. Environ Pollut 152:431-442

Kokko H, Lindstrom J, Ranta E, Sipila T, Koskela J (1998) Estimating the demographic effective population size of the Saimaa ringed seal (Phoca hispida saimensis Nordq.). Anim Conserv 1:47-54

Krafft BA, Kovacs KM, Andersen M, Aars J, Lydersen C, Ergon T, Haug T (2006) Abundance of ringed seals (Pusa hispida) in the fjords of Spitsbergen, Svalbard, during the peak molting period. Mar Mamm Sci 22:394-412

Krylov VI (1990) Ecology of the Caspian seal. Finnish Game Res 47:32-36

Marsh H, Sinclair DF (1989) Correcting for visibility bias in strip transect aerial surveys of aquatic fauna. J Wildl Manag 53:1017-1024

> Moore SE, Huntington HP (2008) Arctic marine mammals and climate change: impacts and resilience. Ecol Appl 18:157-165

> Oigard TA, Haug T, Nilssen KT (2014) Current status of hooded seals in the Greenland Sea. Victims of climate change and predation? Biol Conserv 172:29-36

> Pollock KH, Kendall WL (1987) Visibility bias in aerial surveys-a review of estimation procedures. J Wildl Manag 51:502-510

Pollock KH, Marsh HD, Lawler IR, Alldredge MW (2006) Estimating animal abundance in heterogeneous environments: an application to aerial surveys for dugongs. J Wildl Manag 70:255-262

Potelov V (2003) Estimated pup production of harp seals Pagophilus groenlandicus in the White Sea, Russia, in 2000. ICES J Mar Sci 60:1012-1017

> Quang P, Becker E (1997) Combining line transect and double count sampling techniques for aerial surveys. J Agric Biol Environ Stat 2:230-242

R Core Team (2014) R: a language and environment for statistical computing. R Foundation for Statistical Computing, Vienna

Rumjancev VD, Vorozhcov GA, Huraskin LS, Jusupov MK (1975) Sostojanie zapasov kaspijskogo tjulenja i perspektivy ih ispol'zovanija. Trudy Vsesojuznogo nauchnoissledovatel'skogo instituta morskogo rybnogo hozjajstva i okeanografii 108:185-189

Salberg AB, Haug T, Nilssen KT (2008) Estimation of hooded seal (Cystophora cristata) pup production in the Greenland Sea pack ice during the 2005 whelping season. Polar Biol 31:867-878

Schaber M, Haslob H, Huwer B, Harjes A and others (2011) The invasive ctenophore Mnemiopsis leidyi in the central Baltic Sea: seasonal phenology and hydrographic influence on spatio-temporal distribution patterns. J Plankton Res 33:1053-1065

Skalski J, Ryding K, Millspaugh J (2005) Wildlife demography: analysis of sex, age, and count data. Elsevier Science, San Diego, CA

Southwell C, Paxton CGM, Borchers D, Boveng P, Rogers T, de la Mare WK (2008) Uncommon or cryptic? Challenges in estimating leopard seal abundance by conventional but state-of-the-art methods. Deep-Sea Res I 55:519-531

Speckman SG, Chernook VI, Burn DM, Udevitz MS and others (2011) Results and evaluation of a survey to estimate Pacific walrus population size, 2006. Mar Mamm Sci 27: $514-553$

Stenson GB, Rivest LP, Hammill MO, Gosselin JF, Sjare B (2003) Estimating pup production of harp seals, Pagophilus groenlandicus, in the Northwest Atlantic. Mar Mamm Sci 19:141-160

Sundqvist L, Harkonen T, Svensson CJ, Harding KC (2012) Linking climate trends to population dynamics in the 
Baltic ringed seal: impacts of historical and future winter temperatures. Ambio 41:865-872

Vorozhcov GA, Rumjancev VD, Huraskin LS, Jusupov MK (1972) Sostojanie zapasov kaspijskogo tjulenja i perspektivy ih ispol'zovanija. In: Biologicheskie resursy Kaspijskogo morja. KaspNIRKH, Astrakhan, p 56-58

Wilson S, Kasimbekov Y, Ismailov N, Goodman S (2008) Response of mothers and pups of the Caspian seal, Phoca caspica, to the passage of icebreaker traffic. In: Boltunov

Editorial responsibility: Clive McMahon,

Darwin, NT, Australia
A (ed) Marine mammals of the Holarctic. Collection of Scientific Papers, Marine Mammals Council, Odessa, p 593-595

Wilson SC, Eybatov TM, Amano M, Jepson PD, Goodman SJ (2014) The role of canine distemper virus and persistent organic pollutants in mortality patterns of Caspian seals (Pusa caspica). PLoS ONE 9:e99265

Wood SN (2006) Generalized additive models: an introduction with R. Chapman \& Hall/CRC, Boca Raton, FL

Submitted: February 11, 2015; Accepted: June 25, 2015

Proofs received from author(s): September 4, 2015 